\title{
DETERMINATION OF KINETIC PARAMETERS OF CHEERY TREE PYROL YSIS USING KISSINGER METHOD
}

\author{
UDC 582.734.6:628.475
}

\author{
Milan Protić ${ }^{1}$, Ana Miltojević ${ }^{1}$, Miomir Raos ${ }^{1}$, Petar Đekić ${ }^{2}$ \\ ${ }^{1}$ University of Niš, Faculty of Occupational Safety, Niš, Serbia \\ ${ }^{2}$ College of Applied Technical Sciences, Niš, Serbia
}

\begin{abstract}
In the global quest for substitution of fossil fuels, biomass is regarded as one of the most promising alternatives. Thermochemical conversion is one of the dominant biomass-to-energy processing routes with pyrolysis as one of the options that gained importance in recent years. In this paper pyrolysis experiments of cheery tree samples were performed. The objective of this research was to determine selected physical and chemical properties of cheery related to thermochemical conversion. The samples were pyrolysed in a thermogravimetric analyzer in an inert, nitrogen atmosphere at four different heating rates $1,2,5$ and $10^{\circ} \mathrm{C} / \mathrm{min}$. Pyrolysis occurred, as expected, in threesteps: loss of moisture and light volatiles, active and passive pyrolysis. With an increase in heating rate, a lateral shift of the maximum rate of weight loss for the thermal decomposition to higher temperatures was observed, as well as an increase in the amount of residual char. Moreover, kinetic studies were performed using the Kissinger method. The activation energy was calculated to be $155.26 \mathrm{~kJ} / \mathrm{mol}$, while the pre-exponential factor was $1.685 \times 10^{12} \mathrm{~min}^{-1}$. Obtained results are comparable to values reported in the literature. The Kissinger method is straightforward and offers the possibility for fast and reliable determination of kinetic parameters.
\end{abstract}

Key words: thermochemical conversion of biomass, cheery tree, thermogravimetric analysis, pyrolysis, kinetic parameters, Kissinger method

\section{INTRODUCTION}

Solar and wind energy are leading the way towards the global renewable energy transition. However, one of the main problems associated with these two energy resources is their intermittent character. Biomass can be regarded as one of the main alternatives as an aid in solving this problem. Some of the comparative advantages of biomass are its availability, sustainability and contribution toward combating global warming. Additionally,

Received November 10, 2019 / Accepted December 6, 2019

Corresponding author: Milan Protić

Faculty of Occupational Safety. Čarnojevića 10a, 18000 Niš, Serbia

E-mail: milan.protic@znrfak.ni.ac.rs 
biomass has low sulfur content, fuels produced from biomass have relatively low price and biomass processing technologies produce residues that can be further used. A great number of processes exist for converting solid biomass into usable fuel form. Thermochemical conversion is one of the dominant processing routes with pyrolysis as one of the options that gained importance in recent years.

Biomass pyrolysis is a process of thermal decomposition of solid biofuel in an inert atmosphere. The process is very complex and complete mechanisms of biomass pyrolysis are still not fully understood. The intricacy of biomass decomposition process arises from its complex structure. Biomass is composed of lignin, cellulose and hemicellulose as main building blocks, and each of these natural polymers has highly distinctive reactivity [1], [2]. However, according to [3] array of consecutive reactions can be integrated into one stage global single reaction.

Mathematical modelling of the pyrolysis process is needed in order to predict the quality and quantity of produced gas. Modelling can be performed only if reliable kinetic parameters are known or experimentally determined. Kinetic studies must be based on reliable data from thermally stimulated studies. While a number of experimental setups are available for collecting the data, thermogravimetric analyzers are the most widely applied instruments [4]. In these instruments, a small sample is exposed to a controlled temperature program, while mass loss and temperature are precisely measured in real time. Data collection should be performed according to ICTAC Kinetics Committee recommendations for collecting experimental thermal analysis data for kinetic computations [5]. Experiments can be performed in isothermal or constant heating rate conditions. Both options have their own advantages and drawbacks [6], but constant heating rates experiments are used more frequently. Regardless of the method used, multiple heating rates or multiple temperature programs should be used. In order to avoid sample temperature deviations associated with self-heating/cooling samples of small mass, less than $10 \mathrm{mg}$ should be used [5] [7]. A subsequent kinetic study should follow ICTAC recommendations [6]. In literature, a large body of methods for kinetic computations has been proposed and they can be broadly divided into model-free and model fitting methods.

Biomass kinetic studies gained importance in recent years. Maia and co-workers performed thermal degradation experiments of red pepper waste as solid biofuel [7]. Thermogravimetric experiments were performed with three heating rates $5{ }^{\circ} \mathrm{C} / \mathrm{min}, 7.5$ ${ }^{\circ} \mathrm{C} / \mathrm{min}$ and $10{ }^{\circ} \mathrm{C} / \mathrm{min}$ in an oxidative atmosphere. Ozawa-Flynn-Wall method was used for determination of kinetic parameters. Konwar et al. studied how the addition of biomass influences the pyrolysis behavior of low-rank sub-bituminous coal [8]. Pyrolysis experiments were performed in a nitrogen atmosphere with linear heating rates of 5,10 and $20{ }^{\circ} \mathrm{C} / \mathrm{min}$. The authors used five methods for calculating activation energy and pre-exponential factor and concluded that the Kissinger method was one of the best methods to determine kinetic parameters of coal and coal/biomass blends. Recently, Santos and co-workers [9] have used Ozawa-Flynn-Wall, Kissinger-Akahira-Sunose and Friedman method for determining kinetic parameters for defective coffee beans.

Considering this, we decided to investigate the thermal decomposition of cherry wood samples in an inert, nitrogen, atmosphere and to determine kinetic parameters of cheery tree pyrolysis using the Kissinger method. 


\section{MATERIALS AND METHODS}

\subsection{Sample and sample preparation}

The evaluation of kinetics parameters of biomass pyrolysis was carried out using the samples of cheery tree. The samples were debarked, cut into smaller pieces and dried at $105{ }^{\circ} \mathrm{C}$ to a constant mass. After drying they were pulverized using mortar grinder Fritsch Pulverisette 2 (FRITSCH GmbH, Weimar, Germany) and then sieved using vibratory sieve shaker Fritsch Analysette 3 Spartan (FRITSCH GmbH, Weimar, Germany), according to EN ISO 14780:2017 [10]. The samples with particle sizes of $<100 \mu \mathrm{m}$ were used for TGA experiments.

\subsection{Thermal analysis}

Thermogravimetric analysis was performed on Perkin-Elmer Thermogravimetric Analyzer TGA 4000 (Norwalk, CT, USA). Prior to the analysis, the calibration of the instrument was performed according to the manufacturer's recommendation. The temperature was calibrated by measuring the Curie points for alumel, nickel and perkalloy. For each analysis, approximately $10 \mathrm{mg}$ of sample was placed in the ceramic crucibles. The samples were isothermally held at $30{ }^{\circ} \mathrm{C}$ for $5 \mathrm{~min}$, then heated from 30 to $900{ }^{\circ} \mathrm{C}$ at four different heating rates $\left(1,2,5\right.$ and $\left.10{ }^{\circ} \mathrm{C} / \mathrm{min}\right)$, and then again held isothermally at $900{ }^{\circ} \mathrm{C}$. As a purge gas, nitrogen was used at a flow rate of $20 \mathrm{ml} / \mathrm{min}$. Thermogravimetry (TG) and first derivative thermogravimetry (DTG) curves were obtained using Pyris ${ }^{\mathrm{TM}}$ Software (PerkinElmer, Norwalk, CT, USA).

\subsection{Kinetic study of biomass}

Blasi [3] classified kinetic models of biomass pyrolysis in the following groups:

- one-stage global single reactions;

- one-stage multiple reactions and

- two-stage semiglobal reactions.

In this work, we adopted a one-stage global single reaction kinetic model. According to this assumption, the process of biomass decomposition can be depicted as follows:

$$
\text { Biomass } \rightarrow \text { Volatiles }+ \text { Solid residue (biochar and ash) }
$$

Rate of the reaction, in this case, pyrolysis, depends on the unpyrolyzed mass of biomass [11] and the rate is presented rather through a fraction of material reacted than as concentration, which is common practice in homogenous reactions kinetics. Fraction reacted is usually designated with $\alpha=\left(m_{0}-m_{t}\right) /\left(m_{0}-m_{f}\right)$, where $m_{0}$ stands for the initial mass of the sample, $m_{t}$ is mass of sample in a particular moment and $m_{f}$ is the mass of the sample at the end of the experiment.

Rate of reaction (change of fraction reacted with time) $d \alpha / d t$ is a function of rate constant $k$ and pressure $p$ and can be represented by:

$$
\frac{d \alpha}{d t}=f(k, \alpha, p)=k f(\alpha) h(p)
$$

where $f(\alpha)$ is the reaction (kinetic) model. 
Most thermal studies are conducted in atmospheric conditions, meaning that term $h(p)$ can be omitted from eq. (1). Therefore eq. (1) can be written as:

$$
\frac{d \alpha}{d t}=f(k, \alpha)=k f(\alpha)
$$

Arrhenius equation can be used for expressing reaction rate $k$ change with temperature $T$ :

$$
k(T)=A e^{-\frac{E_{a}}{R T}}
$$

where $A$ is frequency (or pre-exponential) factor, $E_{a}$ is activation energy and $R$ is universal gas constant. After substitution of eq. (3) in eq. (2) one can get:

$$
\frac{d \alpha}{d t}=A e^{-\frac{E_{a}}{R T}} f(\alpha)
$$

Eq. (4) is the most common expression for a basic kinetic equation.

\subsubsection{Kissinger method}

In this work, the Kissinger method [12], [13] was selected for the determination of kinetic parameters: activation energy and pre-exponential factor. For the development of the Kissinger equation, we follow [14]. Kissinger method is a simple, reliable and modelfree kinetics method that is rigorously correct and isoconversional for first-order reactions and excellent approximation for $n^{\text {th }}$ order, nucleation growth and distributed reactivity reactions [15].

The first step in Kissinger equation development is differentiation of eq. 4 by parts:

$$
\frac{d}{d t}\left[\frac{d \alpha}{d t}\right]=A e^{-\frac{E_{a}}{R T}} \frac{d}{d t}[f(\alpha)]+A f(\alpha) \frac{d}{d t}\left[e^{-\frac{E_{a}}{R T}}\right]
$$

The derivative of the first term on the right-hand side of eq. (5) can be represented by:

$$
\frac{d}{d t}[f(\alpha)]=f^{\prime}(\alpha) \frac{d \alpha}{d t}
$$

while the second term can be calculated as:

$$
\frac{d}{d t}\left[e^{-\frac{E_{a}}{R T}}\right]=\frac{E_{a}}{R T^{2}} e^{-\frac{E_{a}}{R T}} \frac{d T}{d t}
$$

Last term in eq. (7) is the heating rate $\beta=d T / d t$. After substitutions of eq. (6) and eq. (7) in eq. (5) one can get:

$$
\frac{d}{d t}\left[\frac{d \alpha}{d t}\right]=A e^{-\frac{E_{a}}{R T}} f^{\prime}(\alpha) \frac{d \alpha}{d t}+A f(\alpha) \frac{E_{a} \beta}{R T^{2}} e^{-\frac{E_{a}}{R T}}
$$


Taking into account that the maximum reaction rate occurs when $\frac{d}{d t}\left[\frac{d \alpha}{d t}\right]=0$, and that for max. reaction rate $T=T_{\max }$, eq. (8) can be transformed into:

$$
0=A e^{-\frac{E_{a}}{R T}} f^{\prime}(\alpha) \frac{d \alpha}{d t}+A f(\alpha) \frac{E_{a} \beta}{R T^{2}} e^{-\frac{E_{a}}{R T}}
$$

After elementary manipulations and inserting rate equation, eq. (9) becomes:

$$
0=A e^{-\frac{E_{a}}{R T}} f^{\prime}(\alpha)+\frac{E_{a} \beta}{R T_{\max }^{2}}
$$

Rearranging terms and taking the natural algorithm of eq. (10), one can get:

$$
\ln \left[\frac{\beta}{T_{\max }^{2}}\right]=\ln \left[\frac{A R}{E_{a}}\right]+\ln \left[-f^{\prime}(\alpha)\right]-\frac{E_{a}}{R T_{\max }}
$$

Eq. (11) is the formulation of the Kissinger equation. Assuming that a decomposition process can be approximated by the first-order reaction $f(\alpha)=(1-\alpha)$, eq. (11) is reduced to the following form:

$$
\ln \left[\frac{\beta}{T_{\max }^{2}}\right]=\ln \left[\frac{A R}{E_{a}}\right]-\frac{E_{a}}{R T_{\max }}
$$

Plotting the left-hand side of the equation versus $1 / T_{\max }$ gives $E_{a}$ and $A$ which correspond to the slope and intercept, respectively.

Process of determination of kinetic parameters using the Kissinger method is straightforward and can be summarized as follows:

- Collecting data (usually by Thermogravimetric (TGA), Differential Scanning Calorimetry (DSC) experiments) using different heating rates;

- Data cleaning and trimming;

- Calculating the derivative thermogravimetric (DTG) signal;

- Locating DTG peaks and reading corresponding temperatures for each heating rate;

- Plotting $\ln \left[\beta / T^{2}\right]$ vs. $1 / T$;

- Curve fitting with linear regression;

- Analyzing the curve (slope, intercept, coefficient of determination $R^{2}$ and residuals) and

- Calculating the kinetic parameters from values of slope and intercept.

\section{RESULTS AND DISCUSSION}

\subsection{Thermogravimetric analysis of biomass samples}

The results of TG analysis of cheery three (TG and DTG curves) obtained at a heating rate of $5{ }^{\circ} \mathrm{C} / \mathrm{min}$ under inert (nitrogen) conditions are given in Fig.1. TG and DTG curves at the heating rates 1,2 and $10^{\circ} \mathrm{C} / \mathrm{min}$ were similar to the ones obtained at $5{ }^{\circ} \mathrm{C} / \mathrm{min}$ heating rate. 
The shapes of TGA and DTG curves indicated that there were three stages of mass loss during the thermal analysis of the cheery tree, as it is the case with woody biomass samples, in general. The temperature ranges of the steps and the weight losses are given in Table 1. The start and the end temperature of each step were determined as we had described before [16] by the intersection of tangents from the linear part and the descending parts of the peak of the DTG curve.

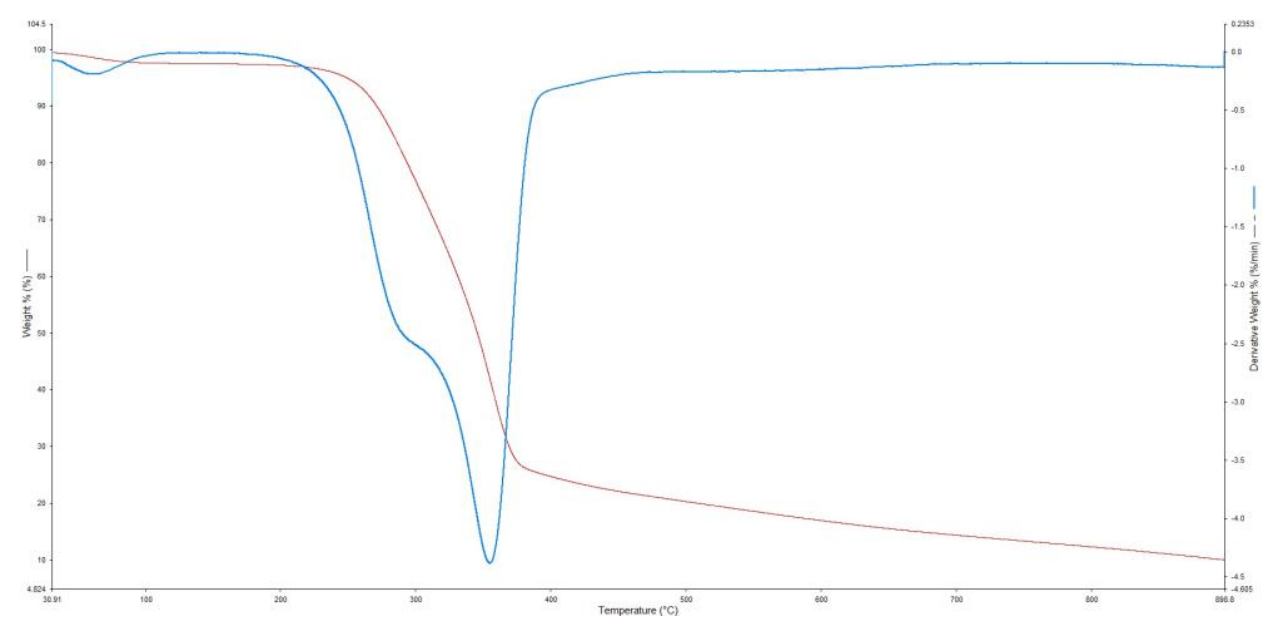

Fig. 1 Thermal analysis of cheery tree in an inert nitrogen atmosphere at a heating rate $\left(5^{\circ} \mathrm{C} / \mathrm{min}\right)$ : TG (red) and DTG (blue) curves

Table 1 Temperature ranges and weight losses during the thermal analysis of cherry tree in an inert (nitrogen) atmosphere

\begin{tabular}{lrrrrrrrr}
\hline & \multicolumn{2}{c}{$1{ }^{\circ} \mathrm{C} / \mathrm{min}$} & \multicolumn{2}{c}{$2{ }^{\circ} \mathrm{C} / \mathrm{min}$} & \multicolumn{2}{c}{$5{ }^{\circ} \mathrm{C} / \mathrm{min}$} & \multicolumn{2}{c}{$10^{\circ} \mathrm{C} / \mathrm{min}$} \\
\cline { 2 - 9 } & $\mathrm{t}\left({ }^{\circ} \mathrm{C}\right)$ & $\mathrm{Wt}(\%)$ & $\mathrm{t}\left({ }^{\circ} \mathrm{C}\right)$ & $\mathrm{Wt}(\%)$ & $\mathrm{t}\left({ }^{\circ} \mathrm{C}\right)$ & $\mathrm{Wt}(\%)$ & $\mathrm{t}\left({ }^{\circ} \mathrm{C}\right)$ & $\mathrm{Wt}(\%)$ \\
\hline Moisture and light & 30 & 100 & 30 & 100 & 30 & 100 & 30 & 100 \\
volatiles evaporation & 70 & 97.60 & 85 & 98.30 & 100 & 97.66 & 115 & 97.86 \\
\hline \multirow{2}{*}{ Active pyrolysis } & 220 & 95.44 & 230 & 96.36 & 245 & 95.45 & 255 & 95.89 \\
& 345 & 27.49 & 360 & 27.62 & 380 & 26.35 & 400 & 26.52 \\
\hline \multirow{2}{*}{ Passive pyrolysis } & 345 & 27.49 & 360 & 27.62 & 380 & 26.35 & 400 & 26.52 \\
& 900 & 1.31 & 900 & 3.07 & 900 & 10.00 & 900 & 13.80 \\
\hline
\end{tabular}

The first step of mass loss corresponding to the initial loss of moisture and volatile matter from the wood sample starts at 30 and ends at $70-115^{\circ} \mathrm{C}$, depending on the heating rate. The thermal decomposition of the wood starts at $220-255^{\circ} \mathrm{C}$. This step is the step of the main devolatilization and is characterized by the major loss of weight. It ends at 245$400{ }^{\circ} \mathrm{C}$ and is followed by a slow further loss of weight. 
TG curves obtained by the decomposition of the cheery tree in an inert (nitrogen) atmosphere at different heating rates are presented in Fig. 2. The increase in the heating rate led to a lateral shift of start and end temperatures of each step to higher temperatures. Also, a lateral shift of the maximum rate of weight loss to higher temperatures with an increase in the heating rate was evident from DTG curves. This lateral shift occurs due to the two factors: (1) effects of the heat transfer from the furnace to the sample at the different heating rates and (2) changes in the kinetics of the thermal decomposition [17] or ether both factors simultaneously can influence the shift. However, the shift may be due to the influence of inter and intra- particle heat and mass transfer [17]. Moreover, an increase in heating rate led to an increase in the amount of residual char that varied from $1,3 \%$ at $1{ }^{\circ} \mathrm{C} / \mathrm{min}$ to $13,8 \%$ at $10{ }^{\circ} \mathrm{C} / \mathrm{min}$.

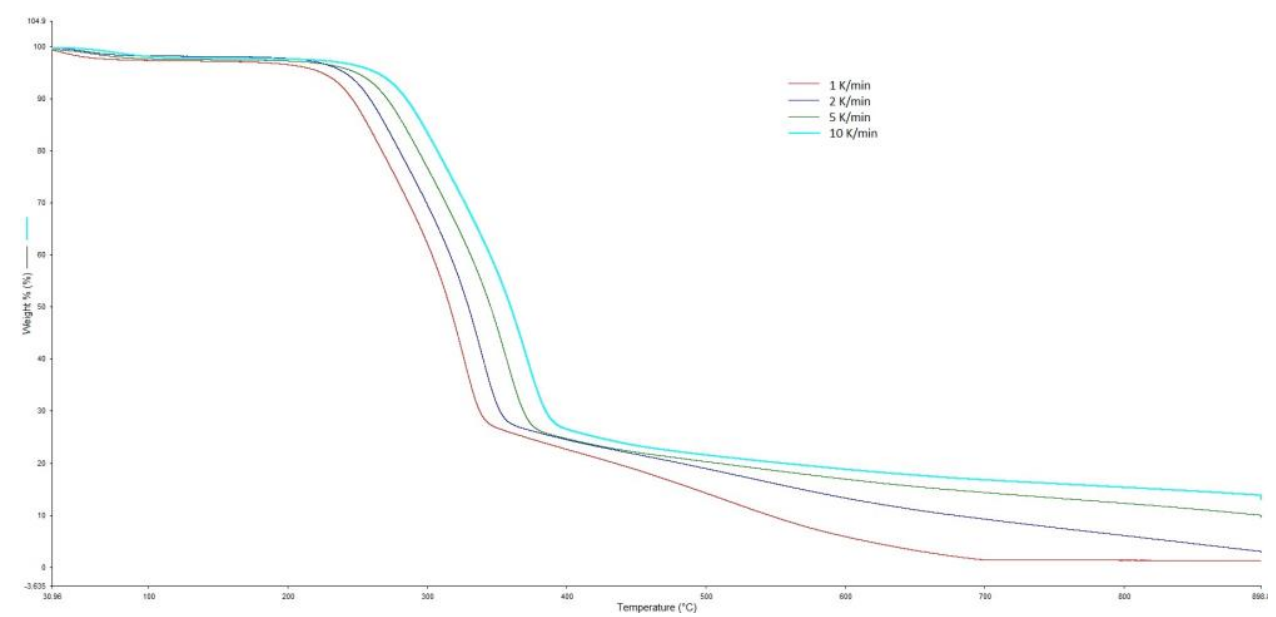

Fig. 2 TGA output for the decomposition of cheery tree in an inert (nitrogen) atmosphere obtained at the heating rates of 1 (red), 2 (dark blue), 5 (green) and 10 (light blue) ${ }^{\circ} \mathrm{C} / \mathrm{min}$.

The cheery tree belongs to woody biomass that is mainly composed of cellulose, hemicellulose and lignin. The thermal decomposition of hemicellulose starts firstly and it is overlapped with the decomposition of cellulose. Lignin shows a gradual loss of weight from about $200{ }^{\circ} \mathrm{C}$. This is in accordance with the results of Shafizadeh [18] who has demonstrated that hemicellulose decomposes mainly between 220 and $320{ }^{\circ} \mathrm{C}$, cellulose between 250 and $360{ }^{\circ} \mathrm{C}$ and that lignin undergoes gradual decomposition between 180 and $500{ }^{\circ} \mathrm{C}$. Thus, the cellulose and hemicellulose components of the wood are mainly responsible for the volatile portion of the product whilst lignin is the main contributor to the char [19]. 


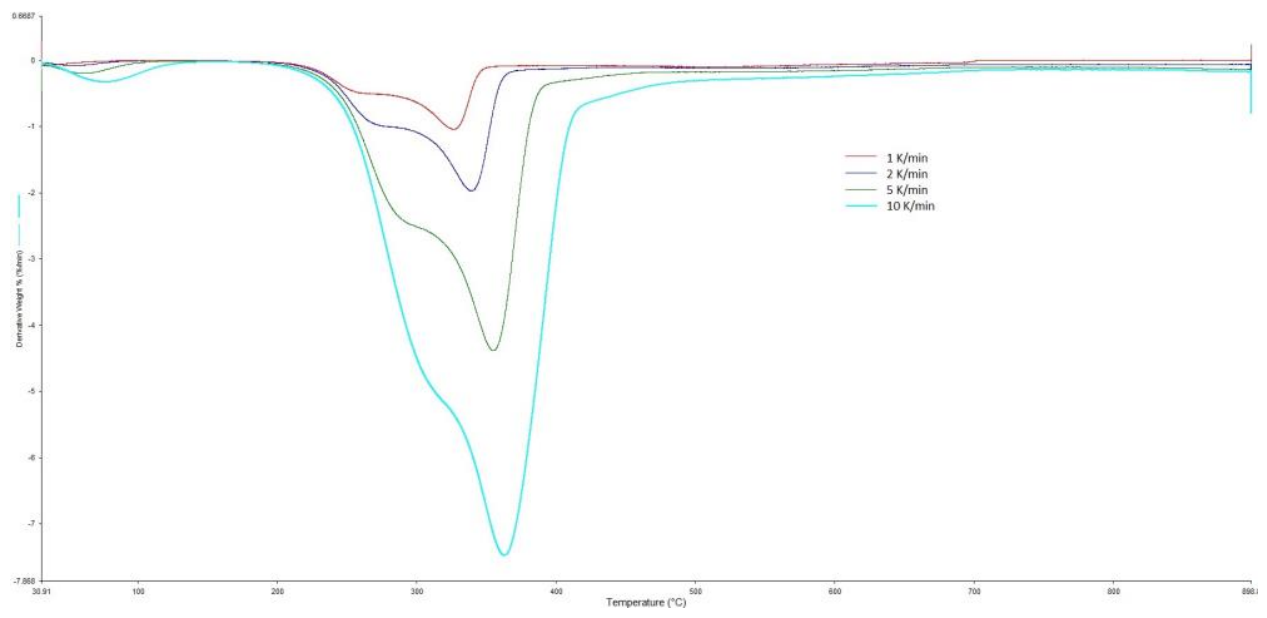

Fig. 3 DTG output for the decomposition of cheery tree in an inert (nitrogen) atmosphere obtained at the heating rates of 1 (red), 2 (dark blue), 5 (green) and 10 (light blue) ${ }^{\circ} \mathrm{C} / \mathrm{min}$.

In the temperature range of the active pyrolysis $\left(250-400{ }^{\circ} \mathrm{C}\right)$, two peaks could be observed in the DTG curve. This is in accordance with the literature data regarding the thermolysis of cellulose, hemicellulose and lignin. The DTG peak at lower temperatures mainly represents the decomposition of hemicellulose and at higher temperatures the decomposition of cellulose. Lignin decomposition occurs throughout the wide temperature range but the main area of weight loss occurs at the higher temperatures. Thus, the thermal decomposition of the woody biomass sample is represented as the combination of the thermal degradation of the individual major biomass components, cellulose, hemicellulose and lignin, as it had been previously described in the literature [17, and the references cited there in].

\subsection{Kinetic parameters}

The Kissinger method was used for determining kinetic parameters. From DTG decomposition curves of cheery tree in an inert (nitrogen) atmosphere (Fig. 3) values for maximal temperature were determined. Obtained values are shown in Table 2.

Table 2 Peak temperatures from DTG curves for different heating rates

\begin{tabular}{lllll}
\hline Heating rate $\beta(\mathrm{K} / \mathrm{min})$ & \multicolumn{1}{c}{1} & \multicolumn{1}{c}{2} & \multicolumn{1}{c}{5} & \multicolumn{1}{c}{10} \\
\hline $\mathrm{T}_{\max }(\mathrm{DTG})\left({ }^{\circ} \mathrm{C}\right)$ & 326.6 & 340.6 & 357.8 & 371.5 \\
$\mathrm{~T}_{\max }(\mathrm{DTG})(\mathrm{K})$ & 599.76 & 613.76 & 630.96 & 644.66 \\
$\ln \left(\beta / \mathrm{T}_{\max } \wedge\right)$ & -12.79306 & -12.14606 & -11.28505 & -10.63486 \\
\hline
\end{tabular}

Additionally, from temperature values, the values of $\ln \left(\beta / \mathrm{T}_{\max }^{2}\right)$ were calculated. These values are also presented in Table 2 . Kissinger plot $\ln \left[\beta / \mathrm{T}^{2}\right]$ vs. $1 / T$ ) for cherry tree is shown in Fig.4. 


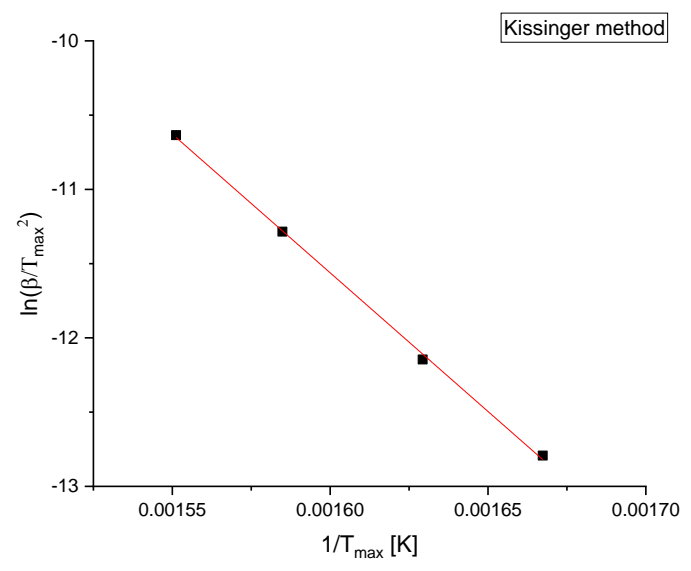

Fig. 4 Kissinger plot of cherry tree

Curve fitting was performed using linear regression. It was concluded that the best fit is provided with the equation:

$$
y=-18674.948 x+18.318
$$

with the coefficient of determination $R^{2}=0.99913$.

The activation energy $\left(E_{a}\right)$ and pre-exponential factor $(A)$ were calculated from the slope and intercept of the regression line [20]. The following results were obtained: the activation energy was calculated to be $155.26 \mathrm{~kJ} / \mathrm{mol}$, while the pre-exponential factor was $1.685 \times 10^{12} \mathrm{~min}^{-1}$. Obtained values are in accordance with those from the literature. For example, in the case of poplar wood, the activation energy determined using the Kissinger method was $153.92 \mathrm{~kJ} / \mathrm{mol}$ [20]. Moreover, Li and co-workers reported that $E_{a}$ of hemicellulose, cellulose and lignin were 157, 192 and $196 \mathrm{~kJ} / \mathrm{mol}$, respectively [1].

\section{CONCLUSION}

The results of TG analysis, TGA and DTG curves of the cheery tree showed three different steps of weight loss. The first step, at the lowest temperatures, corresponded to the loss of moisture and lower volatiles. The mass loss in the temperature range $220-$ $400{ }^{\circ} \mathrm{C}$ could be correlated with the decomposition of hemicellulose and the initial stages of cellulose decomposition, while the mass loss at high temperatures is correlated with the later stages of cellulose decomposition. On the other hand, thermal decomposition of lignin occurs throughout the wide range of temperatures. With an increase in heating rate, a lateral shift of the maximum rate of weight loss for the thermal decomposition to higher temperatures was observed, as well as an increase in the amount of residual char. Furthermore, activation energies for the thermal decomposition of cheery tree were calculated by employing the Kissinger method, assuming a first-order rate of reaction. The activation energy was calculated to be $155.26 \mathrm{~kJ} / \mathrm{mol}$, while the pre-exponential factor was $1.685 \times 10^{12} \mathrm{~min}^{-1}$. Obtained results are comparable to values reported in the literature. The Kissinger method is straightforward and offers the possibility for fast and reliable determination of kinetic parameters. 


\section{REFERENCES}

1. K. Y. Li, X. Huang, C. Fleischmann, G. Rein, and J. Ji, "Pyrolysis of medium-density fiberboard: Optimized search for kinetics scheme and parameters via a genetic algorithm driven by Kissinger's method," Energy and Fuels, vol. 28, no. 9, pp. 6130-6139, 2014.

2. M. Carrier, L. Auret, A. Bridgwater, and J. H. Knoetze, "Using Apparent Activation Energy as a Reactivity Criterion for Biomass Pyrolysis,” Energy and Fuels, vol. 30, no. 10, pp. 7834-7841, 2016.

3. C. Di Blasi, "Modeling and simulation of combustion processes of charring and non-charring solid fuels," Prog. Energy Combust. Sci., vol. 19, no. 1, pp. 71-104, Jan. 1993.

4. G. SriBala, H. H. Carstensen, K. M. Van Geem, and G. B. Marin, Measuring biomass fast pyrolysis kinetics: State of the art, vol. 8, no. 2. 2019.

5. S. Vyazovkin et al., "ICTAC Kinetics Committee recommendations for collecting experimental thermal analysis data for kinetic computations," Thermochim. Acta, vol. 590, pp. 1-23, Aug. 2014.

6. S. Vyazovkin, A. K. Burnham, J. M. Criado, L. A. Pérez-Maqueda, C. Popescu, and N. Sbirrazzuoli, "ICTAC Kinetics Committee recommendations for performing kinetic computations on thermal analysis data," Thermochim. Acta, vol. 520, no. 1-2, pp. 1-19, Jun. 2011.

7. A. A. D. Maia and L. C. de Morais, "Kinetic parameters of red pepper waste as biomass to solid biofuel," Bioresour. Technol., vol. 204, pp. 157-163, Mar. 2016.

8. K. Konwar et al., "Effect of biomass addition on the devolatilization kinetics, mechanisms and thermodynamics of a northeast Indian low-rank sub-bituminous coal," Fuel, vol. 256, p. 115926, Nov. 2019.

9. C. M. Santos, L. S. de Oliveira, E. P. Alves Rocha, and A. S. Franca, "Thermal conversion of defective coffee beans for energy purposes: Characterization and kinetic modeling," Renew. Energy, vol. 147, pp. 1275-1291, Mar. 2020.

10. EN ISO 14780:2017 - Solid biofuels - Sample preparation.

11. P. Basu, Biomass gasification, pyrolysis and torrefaction : practical design and theory. Academic Press, 2013.

12. H. E. Kissinger, "Variation of peak temperature with a heating rate in differential thermal analysis," $J$. Res. Natl. Bur. Stand. (1934), vol. 57, no. 4, pp. 217-221, 1956.

13. H. E. Kissinger, "Reaction Kinetics in Differential Thermal Analysis," Anal. Chem., vol. 29, no. 11, pp. 1702-1706, Nov. 1957.

14. R. L. Blaine and H. E. Kissinger, "Homer Kissinger and the Kissinger equation," Thermochim. Acta, vol. 540, pp. 1-6, Jul. 2012.

15. A. K. (Alan K. Burnham, Global chemical kinetics of fossil fuels: how to model maturation and pyrolysis. Springer, 2017.

16. Ana Miltojević, Milan Protić, Petar Đekić, Jasmina Radosavljević, "Thermogravimetric analysis of oak tree - The influence of heating rate on the pyrolysis," in IX International Conference Industrial Engineering and Environmental Protection 2019 (IIZS 2019) October 3rd -4th, 2019, Zrenjanin, Serbia, 2019

17. T. Williams and S. Besler, "Thermogravimetric Analysis of the Components of Biomass," in Advances in Thermochemical Biomass Conversion, Dordrecht: Springer Netherlands, 1993, pp. 771-783.

18. F. Shafizadeh, "Fuels from wood waste," in Fuels from Waste, Academic Press, 1977, pp. 141-159.

19. F. Shafizadeh and G. D. McGinnis, "Chemical composition and thermal analysis of cottonwood," Carbohydr. Res., vol. 16, no. 2, pp. 273-277, Feb. 1971.

20. K. Slopiecka, P. Bartocci, and F. Fantozzi, "Thermogravimetric analysis and kinetic study of poplar wood pyrolysis,” Appl. Energy, vol. 97, pp. 491-497, Sep. 2012. 


\section{PRIMENA KISINDŽEROVE METODE ZA ODREĐIVANJE KINETIČKIH PARAMETARA PIROLIZE TREŠNJINOG DRVETA}

U globalnoj protrazi za zamenom fosilnih goriva, biomasa se smatra jednom od značajnih alternative. Termohemijska konverzija predstavlja jedan od dominantnih načina za iskorišćenje biomase u energetske svrhe dok je piroliza jedna od opcija koja dobija na značaju poslednjih godina. $U$ ovom radu proučavan je proces priolize drveta trešnje u cilju određivanja fizičkih i hemijskih karakteristika, koje se odnose na termohemijsku konverziju, drveta trešnje. Najpre je izvršena piroliza uzoraka u termogravimetrijskom analizatoru, $u$ inertnoj atmosferi azota, na četiri različite brzine grejanja 1, 2, 5 and $10^{\circ} \mathrm{C} /$ min. Piroliza se odvijala, kako se i očekivalo, u tri koraka: gubitak vlage $i$ lako isparljivih volatila, aktivna $i$ pasivna piroiza. Porast brzine grejanja uzrokovao je lateralni pomak ka višim temperaturama svakog koraka termalne degradacije, kao i porast $u$ količini rezidualnog koksnog ostatka. Pored toga, određeni su i kinetički parametri primenom Kisindžerove metode. Izračunato je da aktivaciona energija iznosi $155,26 \mathrm{~kJ} / \mathrm{mol}$, a pre-eksponencijalni faktor $1,685 \times 10^{12} \mathrm{~min}^{-1}$. Dobijeni kinetički parametri su uporedivi sa rezultatima iz literature. Kisindžerova metoda je jednostavna i pruža mogućnost brzog i pouzdanog određivanja kinetičkih parametara.

Ključne reči: termohemijska konverzija biomase, drvo trešnje, termogravimetrijska analiza, piroliza, kinetički parametri, Kisindžerov metod 